Journal of Southeast Asian

\title{
Lost in institution: Learning to write in Midwestern urban mainstream classrooms
}

Yanan Fan

San Francisco State University, fanyanan@yahoo.com

Follow this and additional works at: https://docs.lib.purdue.edu/jsaaea

Part of the Education Commons

\section{Recommended Citation}

Fan, Yanan (2009) "Lost in institution: Learning to write in Midwestern urban mainstream classrooms," Journal of Southeast Asian American Education and Advancement. Vol. 4 : Iss. 1, Article 2. DOI: $10.7771 / 2153-8999.1093$

Available at: https://docs.lib.purdue.edu/jsaaea/vol4/iss1/2

This document has been made available through Purdue e-Pubs, a service of the Purdue University Libraries. Please contact epubs@purdue.edu for additional information.

This is an Open Access journal. This means that it uses a funding model that does not charge readers or their institutions for access. Readers may freely read, download, copy, distribute, print, search, or link to the full texts of articles. This journal is covered under the CC BY-NC-ND license. 


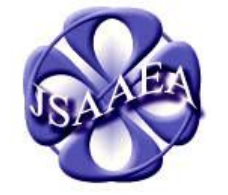

Volume 4 (2009)
Journal of Southeast Asian American

Education \& Advancement

WWW.JSAAEA.org
A peer-reviewed scholarly journal published by the National Association for the Education \& Advancement of Cambodian, Laotian, and Vietnamese Americans (NAFEA)

\title{
Lost in Institution: A Vietnamese Immigrant Student Learning to Write in Midwestern Urban Mainstream Classrooms
}

\author{
Yanan Fan \\ San Francisco State University
}

\begin{abstract}
How do recent immigrant students learn to write in mainstream content area classrooms? This article considers this question in the under-investigated American Midwest contexts where schooling is being reframed by rapid changing demographics. Data for this paper come from an ethnographic case study of second language learning of a Vietnamese $9^{\text {th }}$ grader in an urban school setting. Grounded in a sociocultural view of learning, the author examines (1) how the student negotiated the nature and purpose of writing among inconsistent expectations, objectives and responsibilities in mainstream, and (2) how she was lost in a lack of vision in literacy and the larger institutional environment which encouraged teachers to reward formalism over substance. The author concludes with recommendations for educators in secondary schools to explicitly link pedagogical objectives to language learners' literacy needs and to embedded social values of schooling.
\end{abstract}

As a fast growing number of English language learners (ELLs) enter into America's urban classrooms, their experiences in schools have provoked heated debates regarding ways to address the needs of the ethnically and racially diverse student population, especially in secondary schools (Crawford, 2004; Cummins, 2001; Lucas, 1997; Walqui, 2000). Research has recognized that, compared with younger ELLs, teenage students may find it easier to utilize their first language (L1) to learn English as a second language (L2), for example, while acquiring morphology and syntax (Valdés, 2001). However, the challenge facing ELL teenage students is how to obtain native-like English-speaking levels and how to master academic subject areas simultaneously (Duff, 2005) within a tight timeline of four (high school) to six (middle school and high school) years while they may need as long as five to nine years to accomplish the task (Collier, 1995). This challenge in learning the English language is inseparable from other social challenges such as making a transition to young adulthood, balancing the values treasured in home cultures and in the new cultures (Lucas \& Katz, 1996), and developing a sense of self and others within school (McKay \& Wong, 1996; Harklau, 2000) and with peers (Phelan, Davidson, \& Yu, 1998; Gunderson, 2000). Unfortunately, research on ELLs in mainstream contexts, overall, is much less (Duff, 2005;

\footnotetext{
(c)

SORERIIGHISRESERVEDReaders are free to copy, display, and distribute this article, as long as the work is attributed to the author(s) and the Journal of Southeast Asian American Education \& Advancement, it is distributed for non-commercial purposes only, and no alteration or transformation is made in the work. More details of this Creative Commons license are available at http://creativecommons.org/licenses/by-nc-nd/3.0/. All other uses must be approved by the author(s) or JSAAEA.
} 
Faltis \& Wolfe, 1999) when compared with research focusing on various language programs for ELLs (Valdés, 2001).

The American postindustrial Midwest is among the regions "traditionally less populated either by new immigrants or by bilingual native-born Americans" (Duff, 2005, p. 46). Existing studies of ELL literacy took place primarily in the coastal states in the United States and in immigrant-concentrated metropolises in Canada (Duff, 2001; Faltis \& Wolfe, 1999; Harklau, 1994; Moll, 1992; Valdés, 2001) where the researchers have situated their work in the long cultural history of experiences of close-knit immigrant communities in these regions. Yet the Midwest has seen its school age ELLs triple since 1993 with a fast increase of Spanish speakers and Asian and Pacific Island-language speakers (U.S. Census Bureau, 2003). The area where the reported study took place ranks among the top medium-sized metropolitan areas in the United States for refugee resettlement (Singer \& Wilson, 2006). Its major school district alone houses more than 600 refugee youth representing 62 countries of origin and speaking 42 different languages (Local School District, 2007). Although schooling, institutions, and teaching practices are being reframed by its changing demographics, the Midwest contexts are less familiar and under-investigated. Scholarly work that examines English language and literacy development among ELL school children in this region is rare.

The present article aims to extend our collective understanding of literacy education of ELL adolescents. Drawing on a year-long ethnographic case study of schooling of a Vietnamese immigrant student in a Midwestern urban high school, I explore the complexities of learning and teaching in the mainstream classroom, namely, (a) the student's negotiation of writing expectations across subject matter classes, (b) the nature of mainstream teachers' instructional strategies and concerns, and (c) the interplay between (a) and (b) in the larger context of institutional expectation towards educating ELLs.

\section{Theoretical Framework: Learning as Participating in Contextualized Practices}

A sociocultural perspective guides me in the investigation of second language learning and literacy. I view second language learning as cultural practices participated in by members of a social group, such as a class or a school. Participation involves not only people using past experience to anticipate recurring actions - through the interactional situations and eventsbut also involves their simultaneous negotiation of their social role vis-à-vis other people, their understanding of how the world works, and of how language itself works (Dyson, 1997; Hymes, 1974; Miller \& Goodnow, 1995; Lave \& Wenger, 1991; Rogoff, 1990; Vygotsky, 1978). Therefore, a language learner is an active consumer of resources while participating in the social practices in the classroom. In addition, the sociocultural view of the situatedness of second language learning also requires critical lenses to examine the power relations that exist in the broader institutional and sociopolitical contexts where embedded ideologies, beliefs, and values are reproduced in local social practices (Auerbach, 1995; Barton, Hamilton, \& Ivanic, 2000; New London Group, 1996; Street, 2000). Examining language learning entails inquiries into "how institutional and societal pressures are played out in moment-to-moment classroom interaction, and how to gain a more holistic perspective on teacher-student interactions to aid teacher training and improve practice" (Watson-Gegeo, 1988, p. 575). Similarly, I view literacy, usually in plural forms (Hornberger, 2000), as a 
particular tool that is taught through and learned within particular kinds of practices in and out of school. It is also a set of practices that "are inextricably linked to cultural and power structures in the society" (Wiley, 1996, p. 32).

In North America, researchers have been examining various social, cultural, and political contexts in English learning among immigrant and ELL students (Haneda, 2008; Hancock, 2001; Kramsch, 1995; Liang, 2006; Saville-Troike, 1989; Spolsky, 1990). These contexts range from broad educational movements and policies to particular situations in the classroom, community, or home (Gándara \& Rumberger, 2009; Moll \& Whitmore, 1993; Taylor \& Dorsey-Gaines, 1988; Valdés, 2001). Indeed, as the literature shows, all layers of contexts interact and intertwine with each other. In an ethnographic study of the lives and experiences of four Mexican middle school students, Valdés (2001) examines both the policy and the instructional dilemmas in English language education of immigrant children in California. Setting up her study against the context of California's ban of bilingual education in the 1990s, Valdés analyzed students' use of oral and written languages and the nature of their participation in various programs, classrooms, and communities. She documented how access to English and to academic content was denied by the same institutional structures that were designed to help immigrant students, and how students become frustrated and choose to not learn in such contexts.

Mainstream classroom contexts are particularly addressed by scholars such as Linda Harklau and Patricia Duff. In her three-and-a-half-year ethnographic case study of second language learning in high school, Harklau (1994, 1999, 2000) investigated the effects of tracking on four Chinese ESL students at a large suburban, racially and linguistically diverse northern California high school. She asserted that tracking left many ELL students in lowtrack mainstream programs, which placed the students in less favorable positions in terms of their learning of both the language and the content. Duff's $(2001,2002)$ qualitative studies of immigrant students in Canada link their mainstream experience to their family and community expectations. Despite the students' and their families' strong will to succeed, Duff asserts that mainstream classrooms fail to consider the social, cultural, and linguistic needs of the students.

Through the experiences of real students and teachers in a mainstream classroom in a Midwestern high school, this article joins the line of research on the ELLs' sociocultural experiences and the social implications of secondary immigrant adolescents learning English in schools. The article answers the call for more ethnographic case study research on English language learners from minority ethnolinguistic groups (Genesee, Kindholm-Leary, Saunders \& Christian, 2006), such as Vietnamese, in order to better understand the complexity of second language literacy. In particular, I aim to investigate how literacy practices of the student and her teachers figure into schooling and institutional expectations.

\section{Methodology}

I met my focal student $\mathrm{Thao}^{1}$ while visiting Mrs. Mai, a Vietnamese interpreter and a community liaison working part time at Linton High in the mid-sized Midwestern postindustrial city of Maple Creek. The city has a diverse population of 120,000. During recent decades, Maple Creek has offered refugee resettlement in order to replace the city's continuous population flight due to economic recession and industry decline. Southeast Asian refugees, the largest Asian group, were among the first groups that came to the area. By 
2005, Maple Creek was home to more than 13,000 refugees from 32 countries. More than 60 percent of students in Thao's school are students of color. The school faces challenges as most urban schools do in terms of students' academic performance.

Mrs. Mai recommended that Thao join my project, as Thao needed intensive help with English and with subject matter. When eleven-year-old Thao arrived in the United States in 2001, she did not know much English. She came from central Vietnam to reunite with her parents who had fled to the United States earlier as political refugees. Thao was comfortable and talkative when we had our first informal interview. She shared her ambition and dreams as a high school freshman:

I love to be a model, and help my mom cooking at home and taking [care of] my little sister and my little brother. And when I'm old I want to go college first and get a job, and go to Vietnam and visit my family, get my grandma over here in the United States, live with me, and then, and ... get married with someone and have children and have a happy life, and have an end of happy life. (Thao interview transcripts)

Examining the case of one student can be beneficial in that it entails knowing the entire school to some extent. Thao had a history shared with members of her community (e.g., Vietnamese peers, teachers, and Mrs. Mai) who had their own interpretations of schooling and learning English. These people varied in age group and in relations with Thao. For example, in school, Thao went to seven different mainstream English speaking teachers. She interacted with Mrs. Mai in both Vietnamese and English. With that said, potential stories of many other people involved in this case helped angle my vision and offered a rich repertoire of perspectives. Several teachers participated in the project. Four of them taught Thao 9th grade English, Algebra, Biology, and Science Fiction, respectively. They provided a spectrum of comments on Thao's learning and on various social and political layers in their classroom practices (e.g. the teachers' relationship with the student, their assumptions of how Thao was learning English, and their ways of teaching under the influence of the district, etc.).

\section{Data Collection and Analysis}

Meeting and knowing Thao and her teachers is part of purposefully drawing together information about "the configuration of time and space, of people, and of activity in their physical sites" (Dyson \& Genishi, 2005, p.19). In addition to document collection (e.g., newspaper clippings, census information, student handbooks and yearbooks, class syllabi), I used field notes, interviews, and participant observation in my fieldwork. From the beginning of Fall 2004, I visited Thao at Linton two to three times a week until the end of Spring 2005. Each visit lasted three to four hours, as I followed her to different classes and stayed the whole class time. While observing Thao in classrooms, I jotted down notes on the physical environment, the mood of communications, and the channels the classes used for interaction (Hymes, 1994). These notes were constructed into fieldnotes that documented routine activities and general interactional structures that depicted who said what to whom, in what situation, and for what purposes in recurrent communication events (Hymes, 1994). As I sat very close to Thao in 9th Grade English and Science Fiction classes, I audio-taped her 
interaction with teachers and classmates by using a lapel microphone attached to the shoulder strap of my handbag. The audio data supplemented my fieldnotes in that it recorded Thao's speech and the paralinguistic features of volume, stress, pitch, intonation, and even pauses, also key elements in describing her learning.

I followed Thao through several instructional units in most of her classes-Algebra, Biology, World Geography, 9th Grade English, and Science Fiction, though I spent more time with Thao in the last two classes due to the scheduling convenience and focuses of the courses. My observer role varied from classroom to classroom. I had a more active role as a participant observer (Erickson, 1986) in the 9th Grade English and Science Fiction classes because the teachers were more flexible and willing to have me interact and help with Thao's work in one way or another. In other classes, I was just an observer, sitting in a remote spot away from everyone, due to the seating arrangement and comfort levels of the teachers.

I conducted five informal one-on-one interviews with Thao. Each interview lasted about an hour. We also spoke briefly after each observation session when Thao explained her reactions to the activities. In both situations, I usually started with a general question like "What do you think of today's class (or activity, lecture, writing assignment, etc.)?" The purpose was to give Thao enough space to share what she thought was important. I then followed with the 'why' questions and probed for personal information about her learning experiences and family background (e.g., "Tell me more about your middle school in Vietnam," or "Wow, you had a Japanese-speaking neighbor helping you with English? How did that go?"), her opinions on issues concerning learning English in various situations and subject matters (e.g., "In which class do you think you can get most help with English and why?", "Which subject do you enjoy the most?", and "Why is [a class] difficult or easy?), and her explanations of her work, participation, and strategies in learning English (e.g., "How did you manage to get all these good grades?", "Do you like group work in this class?", and "Why or why not?"). During these conversations, I used simple spoken English to leave Thao enough time and space to share her stories. I also interviewed Thao's teachers, language aide, and counselor two to three times over the course of the school year. Topics in these interviews covered the teachers' perspectives on, and experience in working with Thao and ELLs in general. The teachers also commented on policy issues in the School District. Overall, my questions were open-ended, inviting all my interviewees to describe their experiences, explain their perspectives, and comment on some particular events that had occurred during the study.

With the research question in mind, I read the fieldnotes line by line multiple times and named preliminary coding categories (e.g., Thao's appearance, grades, book reports, reading opportunities, writing opportunities, participation structures, group work). Data was then arranged chronologically and by the setting (or physical situations of classrooms). Based on Hymes (1974) and inspired by Dyson \& Genishi (2005), I selected events (to be exact, language events) as my units of analysis. These events are activities organized by way of using language with diverse kinds of participants, with whom Thao constructs her schooling experience. In this inductive process, I noticed some events contained typical interactional patterns and routines for each setting, especially in mainstream classrooms. After I located these events, I looked across time, settings, and events in order to develop thematic data analysis categories that later replaced or merged the preliminary coding categories, or made them sub-categories. For instance, "reading opportunities" and "writing opportunities" became sub-categories of both "pedagogical practices" and "identity and socialization." 
Finally, I selected key events for close study. These episodes were either representative of the routine practices, or theoretically rich in unraveling the dynamics of the case. They provided a space in which I could use data from multiple sources, including those that were not directly related to these classroom episodes (e.g., comments from interview transcripts that informed the events and practices examined). A multitude of data and of perspectives on the data provided me with contrasting yet complementary views of the nature of Thao's participation in social practices of learning English in school.

\section{The Findings: Lost in Institution}

In this section, I use classroom vignettes to describe how Thao negotiated various writing expectations in mainstream classroom routine activities. I briefly describe perspectives of Thao's teachers towards working with ELLs in the context of Linton. I argue that while negotiating different reading and writing expectations in mainstream classrooms, Thao was lost. Lack of support for Thao's participation in the classroom coupled with the institutional constraints on her teachers' practice negatively impacted her learning.

\section{“Write Down What I Say!" Forced Participation in Controlled Dictation}

On a day like many others in World Geography, Mr. Irving read to the class about Confucius from a textbook and then called the students' attention to the routine worksheet activity. "Now, on the sheet, write down what I say. And if you want a grade, better find your pencil!" He was ready to read out all of the answers.

Thao flipped through the pages - note-taking, explaining concepts, matching, filling the bulleted blanks with Confucius's ways of teaching, and summarizing Confucius's main ideas. Mr. Irving continued to dictate answers and wait for the students to take notes. As he reminded everyone from time to time, if they worked hard and wrote down everything he said, they would get good grades. Thao switched to a colored pencil as all her pencils quickly wore out. She tried to follow the teacher. Given his fast speech, Thao gradually lost words and sentences and her handwriting grew sketchier and more unrecognizable as the exercise reached its end. She received an A for her efforts to follow her teacher's directions and for turning in her work on time.

The objective of this worksheet dictation in World Geography was to cover the required content through mechanical writing without composing. The teacher assumed a role as the authority of content area, disseminating knowledge without discussion or negotiation with the students. Expectations towards students as a whole were to follow the teacher's directions and to transcribe the information the teacher dictated. In such a participation structure (Philips, 1972), in which the teacher dominated most of the interactions, students were a generic group responding mostly through physically "doing" the steps. Thao and her peers became passive participants having no opportunity to socialize and interact with one another or with the teacher over the course of the writing activity.

\section{“Just Write Something...” Fake Participation in Writing for Tokens}

In Science Fiction, Mr. Richards coupled free-writes with viewing movie clips. Before Halloween, he gave a brainstorm assignment. "If you were about to die, what would go 
through your mind? In honor of Halloween, the annual celebration of death, I just want to know and I want you to write about it, and I have a short movie. I want you to write half a page. Right now!" Students sat individually in rows and columns in two matrixes facing each other, leaving an aisle in the middle of the room. Thao was playing with her lip-gloss at her desk in a corner when she suddenly heard Mr. Richard saying that he would check their writing. She quickly took out a blank sheet from her folder, "What the question?" she asked me who was sitting close to her. A few minutes later, Thao showed me her writing.

10/29/04 Thao

I will think that I will never see my family and mine mind is my dad and my mom and two little brother, little sister, and another mine mind is my family in my country I will never see them again.

Some of Thao's classmates were talking about neighbors who died in Iraq just two days before. Others were listening or sleeping. Mr. Richards had to raise his voice when announcing he was going to check the writings when he patrolled around the room. "You guys didn't take your notes, uh? It's called 'I-don't-care-about-my-grades', uh?' Before he reached Thao, no one on Thao's side of the room wrote anything. Mr. Richards changed his tone upon seeing Thao's page. "Thank God we have someone pushing you to do the right thing!" Mr. Richards quickly stamped a little violin on the paper right away without even reading what Thao wrote. After watching Mr. Richards roaming away to check the rest of the students, Thao turned to me with a big proud smile. She showed me the stamp, as well as 7 other stamps she had received. "I get A if I have more!" Thao was hopeful.

During a free-write that required more expository writing, Thao's challenge in language and expression became all the more evident. She wrote the following passage to respond to a given statement from Mr. Richards-"By agreeing or disagreeing with this statement: E.T. (E.T. The Extra-Terrestrial) is about love, the one power in the universe that can not be controlled."

I think is a scare movied because ET is a human come to

Earth down in the city and Elliot a little boy found

ET and be friend with him one day Elliot was lot and

his mom was so worry and call the police and

Elliot was come back home with his eye is all red,

his mom ask him what happen he be quite

it run to his room a next day

ET was is in the water and die

Elliot brother was take the bike and find

ET and take ET to his house and tell his mom

what in the room, his mom was hold the and

walk to the room and she drop her coffe down

and her kids to get out because she scare of that

monster, Elliot was cry and say live me I want ET

if ET die and Elliot is die and the flower growing

up and ET is not die because is a magic ET

Alive in the End that movies, Elliot was so happy 
and they family was let ET go back to Earch.

Instead of stating a position, Thao wrote a sketchy summary to describe what happens in the movie. Her writing caught many detailed episodes such as the dramatic reaction of the little boy's mother upon seeing the sick E.T. Thao also incorporated dialogues to depict how anxious the little boy was when E.T. appeared to be dying. However, Thao needed help with vocabulary, syntax, grammar, and organization. Above all, she needed support to go through the whole process of reading, understanding the question, and writing the response that was relevant.

The goal of the two free-write routine activities, as Mr. Richards stated in the syllabus, was to create opportunities for students to reflect the meaning of life and to enjoy some personal and imaginative writings. Students were expected to write something without having to comply with particular genres and styles. There was no scaffolding to support students' writing process. Students, who managed to write, worked alone. As long as they put some words on paper, they would get a token, an exchange for a better final grade. Mr. Richards' feedback was nothing but a stamp - no other comment or suggestion. For Thao, the stamps were symbols of good work and teacher recognition. Due to lack of teacher's support and a community of peers working together, Thao developed coping strategies of never missing any writing assignments and always using summaries to respond to writing exercises. She took it as a successful strategy because her stamps were accumulating quickly.

\section{Guided Participation? Drafting and Revising}

In the English Language Arts class, Thao experienced new ways of participation different from those in World Geography and Science Fiction. She pointed out many times in our conversations her disadvantage of not knowing what the teacher was asking and how to say or respond to many things. Though eager to adopt her "successful" experiences (e.g., to cooperate by always turning in work on time and always copying teachers' notes) in getting full grades in the other two classes, Thao was helpless and left wondering why it was so difficult to do so in English.

One typical writing activity in class was practicing the five-paragraph essays, which was geared towards the approaching exam season, according to Mrs. Turner. One day the teacher used a sample outline to present how to organize ideas in a five-paragraph essay. She then asked class to come up with three supporting ideas for their own outlines. Thao turned to me, a gesture of invitation to join her brainstorming.

Thao: I say I like go the mall.

Me: Um. Why?

Thao: Because I ... (bites her thumb) Clothes pretty and fun!

Me: Because it's fun?

Thao: Say again?

Me: You said it's fun. I guess you can say three fun things about that.

Thao: (immediately follows me) It's fun to go to mall. Uh, a lot stuff pretty. A lot clothes pretty! And I buy clothes.

Me: What else? 
Thao: I like the food. The food is delicious. (she quickly writes it down) The problem is noisy and sound.

Thao realized that Mary, a classmate sitting nearby, had completed her outline. She signaled her to pass the worksheet. After browsing Mary's outline, Thao was bursting with excitement. She noticed Mary used many fancy words such as "furthermore" and "however" in her outline, and she remembered having a list of such words and quickly dug it out from her folder.

Thao: (to Mary, holds the conjunction sheet titled "Common Transitional Words or Phrases and Their Uses") Oh, you can use this? You can use this?

Mary: (responds positively.)

Thao: Oooh! Why not you TELL me?

Mary: (said she thought Thao had known already)

Thao: No, I did not! (turns to me) We can do this! I'll COPY this! Thao almost shouted.

Mary: (reminds Thao that she should think about the words, and then add the idea. She points to her writing to show how she did that briefly.)

Thao: OK.

Thao read the sample sentences on the conjunction words sheet and was looking for things she could use. She wanted to copy some sentences to her outline as well. She gave me one example:

Thao: I like go the mall. Somewhat later, I go into the mall. Then, second one is...

Me: What do you mean?

Thao: Look! SHE had it in here! (points to Mary’s outline)

On the final outline Thao submitted the next day, however, she did not include ideas she brainstormed previously, such as shopping for clothes and enjoying snacks at the food court. Instead, she chose to put the phrase "long drive" as her first supporting idea and "limited parking" the second. Both ideas were offered in teacher's sample. Thao did not seem to understand the connection between the sample outline, the conjunction word list, and her own assignment. "I don't know what I should write," she said, but she assured me that the teacher's sample had to be the model to follow, literally word for word, though the English teacher was not as generous as the other two teachers.

\section{Grappling With Good Intentions: Words from the Teachers}

While Thao was struggling to get better grades, her teachers admitted that teaching ELLs was a very challenging task they had to handle, though their practices came from good intentions. Many teachers juggled between high expectation for ELLs and sympathy towards them. Mrs. Turner, for example, realized Thao's difficulty in writing, but she decided to give Thao a failing grade to alert her to work harder on vocabulary, syntax, and genre. 
What we're trying to do is we grade them in the quality of their work, ... so they don't just turn their drafts in, you know, [they need to] do it more intensely. (Mrs. Turner interview transcripts)

The Science Fiction teacher, Mr. Richards, struggled with appropriate assessment for ELLs. He was sympathetic towards ELLs due to his experience of having linguistic and cultural shock when traveling outside the United States. Mr. Richards, therefore, believed in creating a friendly environment that keeps students like Thao away from the demanding schoolwork. He did not hesitate to reward Thao's involvement, yet his stamps did not address Thao's specific need in language and literacy.

For Mr. Pierre, Thao's counselor, Thao represented one card among hundreds of freshmen reports. As an English learner himself, he was hopeful for Thao and was in favor of mainstreaming ELLs as a means for students to acquire academic English in a timely manner:

The kids are pretty young, uh, between 14 and 17 years old. So most of the kids have the ability to learn English as their second language pretty quick. And after two or three months, they started being immersed into the culture and then get some English speaking ability. You know, so therefore, these kids can move off to a good situation in regular class. (Mr. Pierre interview transcripts)

He was satisfied with Thao's overall performance in her first year because Thao's GPA was well above a passing grade of 1.0. "Vietnamese students are always on the top," the counselor assured me, when he compared Thao with her Latino and African American peers.

Mrs. Evans, Thao's Biology teacher, revealed a common sense of helplessness among mainstream teachers, pointing out they lacked institutional and professional support to better serve ELLs:

Since we get so many students with ESL ... we need those people [language aides] desperately. I can't tell you how many times I have to run down to another Hispanic teacher. Or sometimes I need help with the students. "We're not communicating! Can you help me out?" (Mrs. Evans interview transcripts)

Still, teachers viewed their teaching as acts of goodwill. Given a lack of institutional support and thorough understanding of Thao's challenges, it became a paradox that teachers tried to help the EL students by letting them sink or swim.

\section{Discussion}

Thao's negotiation of writing expectations in the three mainstream classrooms illustrated how the nature of the instructional and institutional contexts shaped her participation in classroom activities and her understanding of doing well in school. On one hand, Thao did not have the same sense as her teachers regarding the goals and problems of various classroom activities. She received high grades for merely following teacher's direction in Social Studies and Science Fiction, rather than for the quality and content of her work. For 
Thao, the purpose of writing seemed to produce what the teacher wanted and, unfortunately, this was reinforced by the good grades she received. She then developed her "successful" toolkit to get good grades (e.g., by imitating/copying writing prompts and samples), hoping to win the same recognition in other classes. With little help from teachers and peers in class, Thao depended on her sensibility from more successful classes, classes that awarded her good grades. On the other hand, her teachers and school personnel offered more sympathy than specific scaffolding, more meaningless tokens than rigorous academic support. The give-away grades left Thao with a false sense of achievement. The interplay of teachers' kindness and Thao's negotiation of rewards and expectations indicated depicted the danger of good intentions in teaching linguistically and culturally diverse students. With globalization and fast demographic changes nowadays, it is unfortunate that teachers and educators continue to witness this generic, enduring problem of formalism in teaching practice (Labaree, 2007). In Thao's case, she was lost in the classroom and institutional environment that encouraged teachers to reward formalism over substance, that is, to carry out teacher assigned tasks rather than learning the essence of writing and content. How we conceptualize literacy among immigrant students, good intentions, and the larger institutional contexts will not only help us to understand why Thao (indeed, along with her teachers) was helpless in the downward cycle of merely coping with school, but also to investigate dimensions of formalism in educating ELLs.

First, a lack of consensus and pedagogical attention on ELL's literacy development and on the nature of participation across all levels of Thao's mainstream classrooms may have limited teachers' instructional options in creating a welcoming, sensitive classroom community that encouraged learning. Traditional instruction still prevailed in Thao's classrooms where teachers transmitted information to students. Class time was divided by teacher-led lectures, teacher-controlled discussions, and in-class assignments, which either was continuously controlled by the teacher, as in the dictation exercise in Thao's Social Studies class, or was totally left open for students without careful scaffolding to support their finishing the assigned task, as evidenced in Thao's Science Fiction and English classes. Although this kind of instructional environment is deemed safe and easy for teachers to control, cultural, social, and pedagogical variation in the areas of literacy opportunities was not available to students. Thao would be particularly benefited from opportunities of using English to communicate in class when learning both the subject matters and the "socially and culturally appropriate ways" of using English (Valdés, 1998). As Thao tried to explore different texts, namely informational summary on the fill-in-the-blanks worksheet, spontaneous free-write on teacher designated topics, and structured expository writing as in the five-paragraph essay, she may have needed to tend to many areas of the English language and literacy skills all simultaneously (Valdés, 2001). For example, the specific text structures, functions of these texts, and the social meaning of learning these texts all require a more multi-dimensional, contextualized development of communicative repertoires (Dyson, 2000; Hornberger, 2000) across reading, writing, listening, and speaking (Duff, 2001).

In addition, second language literacy development refers to the process and product of a natural combination of situating oneself and using English to function in real language contexts in participating in the larger process of social practice (Lave \& Wenger, 1991). As "the construct of participation locates learning activities at the intersection of social interaction and academic accomplishment" (Berry, 2006, p. 494), Thao measured her relationship to the physical and social world and the functions of English in classrooms using 
her writing as symbolic tools. Sadly, she was not offered multiple and varied ways for active involvement with others as a legitimate participant. In other words, Thao had inadequate access to the kinds of social activities and interactions that rendered her understanding of what writing was and why learning to write is important. Under such circumstances, English language learners may tend to rely on "survival strategies"-memorization, blackboard notes, and available samples as when asked to complete original written work (Harklau, 1999, p. 47). Across Thao's mainstream classrooms, different expectations for participation and literate behaviors and different levels of academic expectations sent her mixed message as to what kind of participation was validated, thus confusing her between doing schoolwork and learning schoolwork. As a result and similar to students in Harklau's study (1999), Thao turned most of her writing assignments into verbatim copying of samples provided by the teachers. Surprisingly good grades and lack of constructive feedback on language and quality of work reinforced writing as a formalized exercise.

Secondly, teachers' good intentions created problematic consequences for Thao's learning. Their sympathy and generous grades inevitably validated Thao's illusory success rather than the knowledge and skill she actually required (Labaree, 2000). Thao was given temporary delusions of academic progress, but then was thrown back into frustration about the cruelty of learning in the English Language Arts class. Rubinstein-Avila (2003) contends that teachers' empathy and understanding are fundamental to teaching immigrant students, but such sensitivity does not mean lowering expectations or just feeling sorry for the students. However, for many of Thao's teachers, formalism became an appealing and safe solution they used to ease their anxieties about managing to take care of ELLs and to cover content in regular classrooms. Meanwhile, teachers wished that good grades and credits for attendance would give Thao some confidence and the sense of success she needed to survive high school. When teachers do not have the tools to help ELL students, they fall easily to the norms of the country's educational system stressing "attendance over performance" and encouraging students to "pursue the tokens of academic success rather than to demonstrate mastery of academic content" (Labaree, 2007, p. 119). However, as shown in Thao's case, teachers' good intentions did not meet the academic, social, and linguistic needs of the student, and further misled the student to collect tokens and serve seat times. Valdés (1998) problematizes good intentions and encourages further investigations into the larger institutional assumptions of educating ELLs.

Individuals of good will are not aware that they have become instruments of dominant interests. They are seldom conscious of the fact that power is exercised both through coercion and through consent and that, in many cases, people "consent" to preserving the status quo and to maintaining existing power relationships simply by accepting established practices without question. (Valdés, 1998, p. 15)

Last but not least, the act of any individual teacher is situated in the larger institutional settings that define the possibilities and constraints she or he provides. In Thao's school, an implicit type of tracking was disguised under the formalistic structure of mainstreaming ELLs. In her ethnographic study of four Spanish-speaking middle school students, Valdés (2001) argues against the isolation of immigrant students from native speakers of English and environments that offer interpersonal and academic language. Unlike these students, Thao appeared to have adequate access to authentic language and academic 
contexts; nonetheless, the situation was far from what Thao's counselor hoped would guarantee Thao a nurturing learning environment. She was thrown into an implicit tracking that offered her the maximum number of low-track electives (e.g., Science Fiction, Choir, Physical Education) with those unavoidable required courses. The Science Fiction teacher was straightforward when introducing his course in the interview - that it was designed for ELLs and special education students "out of apprehension that their language proficiency was not sufficient to compete in high-track courses (Harklau, 1999, p. 52) in mainstream classrooms. This ability grouping within mainstream classes in Thao's high school reflected a deficit view of students with different linguistic backgrounds and was unfortunately "formalize[d] and institutionalize[d]" (Harklau, 1999, p. 51). For students like Thao, such tracking tends to produce an "illusion of inclusion" (Valenzuela, 1999, p. 162).

\section{Conclusion}

Immigrant students' negotiation of academic English, participation, and literacy expectations is contingent upon the opportunities brought about by varied instructional and institutional contexts as well as the language ideologies behind them. As evident in this case study, unclear vision of second language literacy development, lack of pedagogical attention to their needs across mainstream classrooms, and inflated grades tended to confuse the student and push her to focus on grades instead of learning. Implicit tracking through electives and lack of professional support to classroom teachers further formalizes such institutional practice, leaving the student little chance to participate in learning.

It is crucial that educators reach an agreement that every teacher is a language teacher and that teaching any subject area involves knowledge of how languages develop, under what conditions they develop, and how to create such conditions for student participation and use of languages in school. This understanding should inevitably be incorporated into everyday teaching. The key is how to clarify pedagogical objectives and social values across different learning situations in schools (Leung, 2001). Classroom activities should create opportunities to interact in various participation structures (Philips, 1972) in order to encourage students to actively draw on their cultural and personal experiences and to link their language with context (Johnson, 1994). Teachers can encourage ELL students to use their second language with English native speakers through setting up compatible pairs (e.g., a native speaker and an ELL student; or two students of different proficiency levels).

Educating ELL students does not mean lowering the standards; rather it requires concerted efforts to improve pedagogy that actively responds to students' second language development. Sympathy and easy grades do not help students learn the vocabulary and discourse that matches the disciplinary subjects. Teachers should learn to distinguish developmental features in students' English and set up clear language teaching objectives, along with the content objectives for each lesson. Further, these objectives should also be revealed explicitly to students so that they understand what is expected of them and how they can actively participate in classroom activities (Echevarria, Vogt, \& Short, 2007).

Finally, teachers cannot make up and carry out this plan alone. Their pedagogy, teaching materials, assessment tools, and the whole process of conducting teaching should be informed by research and continuous professional development. They should also have opportunities to critically examine the political and social implications of their everyday practice and the role they play in reinforcing or challenging institutional assumptions of 
teaching, learning, and educating students from various sociocultural backgrounds. They need to realize that change can and should start in their classroom.

\section{Endnotes}

${ }^{1}$ All names in this manuscript are pseudonyms

\section{References}

Auerbach, E. R. (1995). The politics of the ESL classroom: Issues of power in pedagogical choices. In J. W. Tollefson (Ed.), Power and inequality in language education (pp. 923). Cambridge: Cambridge University Press.

Barton, D., Hamilton, M., \& Ivanic, R. (Eds.). (2000). Situated literacies: Reading and writing in context. London: Routledge.

Berry, R. A. W. (2006). Inclusion, power, and community: Teachers and students interpret the language of community in an inclusion classroom. American Educational Research Journal, 43, 489-529.

Collier, V. P. (1995). Promoting academic success for ESL students. Jersey City, NJ: NJTESOL-BE.

Crawford, J. (2004). Educating English learners: Language diversity in the classroom. Los Angeles: Bilingual Educational Services.

Cummins, J. (2001). Language, power, and pedagogy: Bilingual children in the crossfire. Clevedon, UK: Multilingual Matters.

Duff, P. A. (2001). Language, literacy, content, and (pop) culture: Challenges for ESL students in mainstream courses. Canadian Modern Language Review, 58, 103-132.

Duff, P. A. (2002). Pop culture and ESL students: Intertextuality, identity, and participation in classroom discussions. Journal of Adolescent \& Adult Literacy, 45, 482-487.

Duff, P. A. (2005). ESL in secondary schools: Programs, problematics, and possibilities. In E. Hinkel (Ed.), Handbook of research in second language teaching and learning (pp. 45-64). Mahwah, NJ: Lawrence Erlbaum.

Dyson, A. H. (1997). Writing superheroes: Contemporary childhood, popular culture, and classroom literacy. New York: Teachers College Press.

Dyson, A. H. (2000). Writing and the sea of voices: Oral language down, around, and above writing. In R. Indrisano \& J. R. Squire (Eds.), Perspectives on writing: Research, theory, and practice (pp. 45-63). Newark, DE: International Reading Association.

Dyson, A. H., \& Genishi, C. (2005). On the case: Approaches to language and literacy research. New York: Teachers College Press.

Echevarria, J. Vogt, M., \& Short, D. J. (2007). Making content comprehensible for English learners: The SIOP model ( $3^{\text {rd }}$ ed.). New York: Pearson.

Erickson, F. (1986). Qualitative methods in research on teaching. In M. Wittrock (Ed.), Handbook of research on teaching (3rd ed., pp. 119-161). Washington, DC: American Educational Research Association.

Faltis, C. J., \& Wolfe, P. M. (Eds.). (1999). So much to say: Adolescents, bilingualism, and ESL in the secondary school. New York: Teachers College Press. 
Gándara, P., \& Rumberger, R. W. (2009). Immigration, language, and education: How does language policy structure opportunity? Teachers College Record, 111, 750-782.

Genesee, G., Lindholm-Leary, K. Saunders, W., \& Christian, D. (2006). Educating English language learners. New York: Cambridge University Press.

Gunderson, L. (2000). Voices of the teenage diasporas. Journal of Adolescent \& Adult Literacy, 43, 692-697.

Hancock, C. R. (2001). The teaching of second languages: Research trends. In V. Richardson (Ed.), Handbook of research on teaching ( $4^{\text {th }}$ ed.; pp. 358-369). Washington, DC: American Educational Research Association.

Haneda, M. (2008). Contexts for learning: English language learners in a U.S. middle school. The International Journal of Bilingual Education and Bilingualism, 11, 57-74.

Harklau, L. (1994a). Jumping tracks: How language-minority students negotiate evaluations of ability. Anthropology and Education Quarterly, 25, 347-363.

Harklau, L. (1994b). Tracking and linguistic minority students: Consequences of ability grouping for second language learners. Linguistics and Education, 6, 221-248.

Harklau, L. (1999). The ESL learning environment in secondary school. In C. Faltis \& P. M. Wolfe (Eds.), So much to say: Adolescents, bilingualism, and ESL in the secondary school (pp. 42-60). New York: Teachers College Press.

Harklau, L. (2000). From the "good kids" to the "worst": Representations of English language learners across educational settings. TESOL Quarterly, 44, 35-67.

Hornberger, N. H. (2000). Multilingual literacies, literacy practices, and the continua of biliteracy. In M. Martin-Jones \& K. Jones (Eds.), Multilingual literacies: Reading and writing different worlds (pp. 353-368). Philadelphia: John Benjamins.

Hymes, D. (1974). Foundations in sociolinguistics: An ethnographic approach. Philadelphia: University of Pennsylvania Press.

Johnson, D. M. (1994). Grouping strategies for second language learners. In F. Genesee (Ed.), Educating second language children: The whole child, the whole curriculum, the whole community (pp. 183-211). New York: Cambridge University Press.

Kramsch, C. (Ed.). (1995). Redefining the boundaries of language study. Boston: Heinle.

Labaree, D. (2000). On the nature of teaching and teacher education: Difficult practices that look easy. Journal of Teacher Education, 51, 228-233.

Labaree, D. F. (2007). Education, markets, and the public good: The selected works of David F. Labaree. London: Routledge.

Lave, J., \& Wenger, E. (1991). Situated learning: Legitimate peripheral participation. Cambridge: Cambridge University Press.

Leung, C. (2001). Evaluation of content-language learning in the mainstream classroom. In C. Leung \& C. Davison (Eds.), English as a second language in the mainstream: Teaching, learning and identity. (pp. 177-198). Harlow, UK: Pearson.

Liang, X. (2006). Identity and language functions: High school Chinese immigrant students' code-switching dilemmas in ESL classes. Journal of Language, Identity \& Education, 5, 143-167.

Local School District. (2007). Fall 2006 head count. Lansing, MI: Office of Pupil Accounting and Central Enrollment.

Lucas, T., \& Katz, A. (1996). Promoting secondary school transitions for immigrant adolescents. Washington, DC: ERIC Clearinghouse on Languages and Linguistics. 
Lucas, T. (1997). Into, through, and beyond secondary school: Critical transitions for immigrant youths. McHenry, IL: Delta Systems.

McKay, S. L., \& Wong, S. C. (1996). Multiple discourses, multiple identities: Investment and agency in second-language learning among Chinese adolescent immigrant students. Harvard Educational Review, 66, 577-608.

Miller, P. J., \& Goodnow, J. J. (1995). Cultural practices: Toward an integration of culture and development. In J. J. Goodnow, P. J. Miller \& F. Kessel (Eds.), Cultural practice as contexts for development. (pp. 5-16). San Francisco: Jossey-Bass.

Moll, L., Amanti, C., Neff, D., \& Gonzalez, N. (1992). Funds of knowledge for teaching: Using a qualitative approach to connect homes and classrooms. Theory Into Practice, XXXI, 132-141.

Moll, L., \& Whitmore, K. (1993). Vygotsky in classroom practice: Moving from individual transmission to social transaction. In N. M. E. Forman, \& C. A. Stone (Ed.), Contexts for learning: Sociocultural dynamics in children's development (pp. 19-42). New York: Oxford University Press.

New London Group. (1996). A pedagogy of multiliteracies: Designing social futures. Harvard Educational Review, 61, 60-92.

Phelan, P., Davidson, A. L., \& Yu, H. C. (1998). Adolescents' worlds: Negotiating family, peers, and school. New York: Teacher College Press.

Philips, S. (1972). Participant structures and communicative competence: Warm springs children in community and classroom. In C. B. Cazden, V. P. John \& D. Hymes (Eds.), The functions of language in the classroom (pp. 370 - 394). New York: Teachers College Press.

Rogoff, B. (1990). Apprenticeship in thinking: Cognitive development in social context. Oxford: Oxford University Press.

Rubinstein-Avila, E. (2003). Facing reality: English language learners in middle school classes. English Education, 35, 122-136.

Saville-Troike, M. (1989). The ethnography of communication: An introduction. Oxford, UK: Basil Blackwell.

Singer, A., \& Wilson, J. (2006). From 'there' to 'here': Refugee resettlement in metropolitan American. The Brookings Institution Living Cities Census Series, 1-31.

Spolsky, B. (1990). Introduction to a colloquium: The scope and form of a theory of second language learning. TESOL Quarterly, 24, 609-616.

Street, B. (2000). Literacy events and literacy practices: Theory and practice in the New Literacy Studies. In M. Martin-Jones \& K. Jones (Eds.), Multilingual literacies: Reading and writing different worlds (pp. 17-29). Philadelphia: John Benjamins.

Taylor, D., \& Dorsey-Gaines, C. (1988). Growing up literate: Learning from inner-city families. Portsmouth, NH: Heinemann.

U.S. Census Bureau. (2003). Language use and English-speaking ability: 2000 - Census 2000 brief.

Valdés, G. (1998). The world outside and inside schools: Language and immigrant children. Educational Researcher, 27, 4-18.

Valdés, G. (2001). Learning and not learning English: Latino students in American schools. New York: Teachers College Press.

Valenzuela, A. (1999). Subtractive schooling: U.S.-Mexican youth and the politics of caring. Albany, NY: State University of New York Press. 
Vygotsky, L. S. (1978). The prehistory of written language. In M. Cole, V. John-Steiner, S. Scribner \& E. Souberman (Eds.), Mind in society: The development of higher psychological processes. Cambridge, MA: Harvard University Press.

Walqui, A. (2000). Access and engagement: Program design and instructional approaches for immigrant students in secondary schools. In J. K. Peyton \& D. Christian (Eds.), Topics in Immigrant Education. McHenry, IL: Delta Systems.

Watson-Gegeo, K. A. (1988). Ethnography in ESL: Defining the essentials. TESOL Quarterly, 22, 575-592.

Wiley, T. G. (1996). Literacy and language diversity in the United States. Washington, DC: Center for Applied Linguistics and Delta Systems.

\begin{abstract}
About the Author
Yanan Fan is Assistant Professor in the Department of Secondary Education at San Francisco State University. Her teaching and research interests focus on second language and literacy development among immigrant adolescents. She is a former English teacher in China and completed her Ph.D. in Curriculum, Teaching, and Educational Policy from Michigan State University in 2006.
\end{abstract}




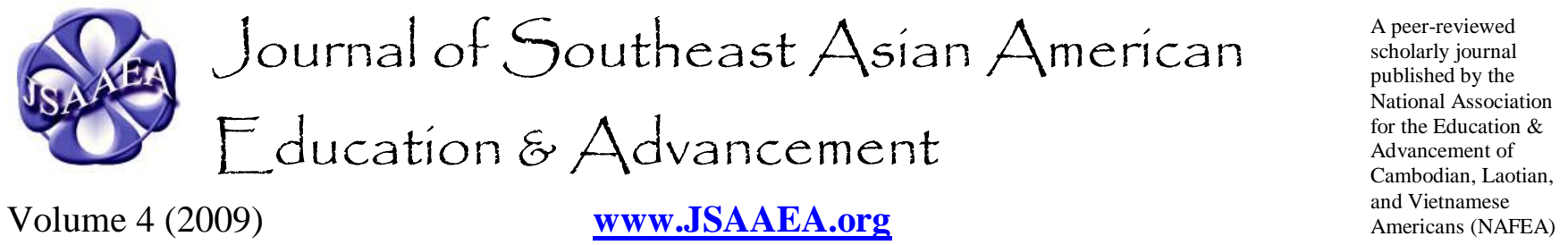

\section{Editor}

Dr. Wayne E. Wright

University of Texas, San Antonio

Associate Editors

Dr. Chhany Sak-Humphry

University of Hawaii

Dr. KimOanh Nguyen-Lam

California State University, Long Beach

\section{Book Review Editor}

Dr. Vichet Chhuon

University of California-Santa Barbara

\section{Creative Works Editor}

Phouang Hamilton

Washington Office of Superintendent of Public Instruction

Editorial Assistant

Mariana Kuhl

University of Texas, San Antonio

Comments and questions for the editorial staff may be directed to jsaaea@ lists.sis.utsa.edu

\section{Editorial Review Board}

\section{Dr. Carl L. Bankston III}

Tulane University

Dr. Phala Chea

Lowell Public Schools

Dr. Changming Duan

University of Missouri, Kansas City

Dr. Nancy H. Hornberger

University of Pennsylvania

Dr. Peter Nien-Chu Kiang

University of Massachusetts, Boston

Dr. Stacey Lee

University of Wisconsin, Madison
Dr. Pollie Bith-Melander

Asian and Pacific Islander Wellness Center

Dr. George Chigas

University of Massachusetts, Lowell

Dr. Sophal Ear

U.S. Naval Postgraduate School

Dr. Samlong Inthaly

Minneapolis Public Schools

Dr. Kevin K. Kumashiro

University of Illinois, Chicago

Dr. David Chanpannha Ley

Montgomery County Public Schools 
Dr. Sue Needham

California State University, Dominguez Hills

Dr. Max Niedzwiecki

Daylight Consulting Group

Dr. Clara Park

California State University, Northridge

Dr. Loan T. Phan

University of New Hampshire

Dr. Karen Quintiliani

California State University, Long Beach

Dr. Fay Shin

California State University, Long Beach

Dr. Yer J. Thao

Portland State University

Dr. Khatharya Um

University of California, Berkeley

Dr. Terrence G. Wiley

Arizona State University
Dr. Bic Ngo

University of Wisconsin-Madison

Dr. Leakhena Nou

California State University, Long Beach

Dr. Mark Pfeifer

Texas A\&M University, Corpus Christi

Dr. Bounlieng Phommasouvanh

Minnesota Department of Education

Dr. Kalyani Rai

University of Wisconsin, Milwaukee

Dr. Nancy J. Smith-Hefner

Boston University

Dr. Myluong Tran

San Diego State University

Dr. Linda Trinh Vo

University of California, Irvine

Dr. Zha Blong Xiong

University of Minnesota

Dr. Kou Yang

California State University, Stanislaus

Doctoral Student Editorial Review Board

Keo Chea

University of Pennsylvania

Loan Dao

University of California, Berkeley

Ha Lam

Arizona State University

Monirith Ly

Texas State University

Rassamichanh Souryasack

University of California, Santa Barbara

Layheng Ting

State University of New York, Albany
Ravy Lao

University of California, Santa Barbara

Vanna Som

Harvard University

Giang Pham

University of Minnesota

Tinou Tran

University of Houston, Texas

Phitsamay Sychitkokhong Uy

Harvard University

Tinou Tran

University of Houston, Texas

Loan Tran

University of California, Santa Barbara 